\title{
Towards the Usefulness and Implications of Segment Reporting Standards
}

\author{
Odia J.O. (PhD) \\ Department of Accounting, University of Benin, Benin City \\ odiajames@yahoo.com, james.odia@uniben.edu \\ Imagbe, V.U \\ Bursary Department ,University of Benin, Benin City \\ usunobunimagbe@gmail.com
}

\section{Doi:10.5901/mjss.2015.v6n6p30}

\begin{abstract}
The paper examines the usefulness and implications of segment reporting standards based on the review of extant literatures. Segment reporting provides information about an entity's operations which enables users of financial reports to assess and make informed decision on the true position and performance of the business and geographical segments a diversified entity is operating. The advocacies to make companies disclose adequately segment information resulted in the issuing of various segment standards such as Statement of Financial Accounting Standards (SFAS) 14 and 131, International Accounting Standards (1AS 14) and IAS 14R and lastly International Financial Reporting Standards (IFRS) 8.The amendments to, and/ or replacement of the standards were due to the reported deficiencies and/or criticisms by users of financial statements and other stakeholders. Following the convergence project of the IASB and US FASB, the IFRS 8 which was a replica of SFAS 131 was adopted for reporting segment information. Although IFRS 8 has been found to result in increased disclosure of segment information, there are various concerns and criticisms of the standard. These concerns and criticisms are significant enough to undermine the usage of IFRS 8 and render it less relevant. Therefore the paper recommends more post implementation reviews by the IASB and academic researches into the IFRS 8 in order to address these concerns and improve the quality of segment reporting standards.
\end{abstract}

Keywords: Segments, segment reporting, accounting standards, SFAS14/131, IAS14/14R, IFRS 8

\section{Introduction}

Segment reporting arose due to the need to better understand the performance of companies. It was to assist users of financial statements with the ability to see what management may do in the future as well as recognize areas the companies get their resources. The United States Financial Accounting Standards Board (US FASB) argued that a company by providing segment information would help users to assess the underlying cause of prior cash flows, performance and future prospect of the company. Basically, Segment reporting involves breaking down the enterprise into its constituent parts or segments, and reporting financial information for each of these. For instance a company can break down its segment operations in a number of ways such as by: industry or type of business (often called line of business, or LoB), geographical area (either in terms of location of operations or location of customers) or by a combination of both of the two.

Segment reporting enables financial statement to: " (1) fully understand the past performance of the entity (2) assess the entity risks and returns and (3) makefull decision about the whole entity". It also helps to analyze the strategies of the company's line of business (Nobes and Parker, 2000; Gregory and Pascale,2010).Segment disclosure can assist users to predict the future cash flows of a company (Tangi and Znao,1999) and value common stock (Boatsman, Behn and Patz,1993). Moreover, segment reporting adds credence to the full disclosure requirements of the generally accepted accounting principles (GAAP) because financial reports have enough details to disclose matters of materiality and still present information that is understandable. The reasons for full disclosure of segment reporting are to describe and provide: " (1) more useful measures of items discovered in the financial statements (2) useful measures of items not found in the financial statements (3) disclosures to assist shareholders and debt holders to evaluate the risks and returns of all items whether recognized or not in the financial statement and (4) provide important information during interim periods while accounting issues are being studied in more depth" (PWC,2008). 
Basically, the segment disclosure entails the internal information used by management aside turnover from external parties (PWC,2008). Knutson (1993) argued segment information was "vital, essential, fundamental and indispensable to investment analysis process". In the survey by the Association for Investment Management and Research (AIMR) in 1999, only $5 \%$ of the respondents linked the improvement in the financial reporting quality to segment reporting. Moreover, $36 \%$ of the analysts believed that segment reporting was important. Improvement in the segment disclosures help investors to: predict future performance, reduce risk profile and lower cost of capital (Botosan,1997; Lambert, Leuz and Verrecchia,2007), reduce insider trading profit,(Park and Shin,2009), improve the forecasting of future earnings (Herrmann and Thomas,2000a) and influence the decisions of equity holders and other stakeholders (Berger and Hann,2003).Hence, users of financial reports are able to see to the prospects and risks of a diversified entity through the segment information as against the aggregated data.

The business and geographical segments are subjected to a lot of risks like impact of technology changes, government policies, exchange rate fluctuation or volatility, international comparative advantages and political instability. In fact, both business and geographical segments reporting were found to impact on perceived risks and also increased trust in the reported entity (Jahmani, 2003).Nevertheless, the factors to consider in order to identify geographical segment include: similar economic and political conditions, relationship between operations on different geographical areas, special risks of operations, exchange control regulations and currency risks. For a business segment, a reporting segment needs to consider the existing profit centre, the nature of the products or services, the production process, markets, marketing methods, and the nature of the regulatory environment. Moreover, some of the factors affecting segment disclosures include: users' request for forecasts and firms evaluation information, company size, industry size, broader base to obtain resources, level of investors' protection, exchange listing and country of domicile (Harris,1998; Archambault and Archambault,2003; La Porta et al, 1998 Street and Gray 2001; Street \& Bryant, 2000). Larger companies and companies listed on more than one stock exchange were found to disclose more segmental information (Prather-Kinsey and Meet 2004; Hermann and Thomas, 1996). Similarly, Hermann et al (1996) concluded that larger companies report more items for each line of business or geographical segment. Also, audit firms impact on the level of segment disclosure. Basically, companies audited by the Big 5/Big 4 audit firms disclosed more segmental information (Prather-Kinsey and Meek, 2004; Glaum and Street, 2003).

The objective of the paper is to consider the usefulness and implications of segment disclosures requirements by major standards setters such as the International Accounting Standards Board (IASB) and the US FASB. The rest of the paper is divided into six sections. The immediate section traces the origin of standards on segment reporting. Sections three and four consider the motivations for the issuance and the criticisms or deficiencies that led to their revisions or replacement of some segment standards. A comparison of some standards is also highlighted. Section five dwells on the composition and controversies of IFRS 8 and compares it with other standards. Section six examines the implications of IFRS adoption on segment reporting. The last section is the conclusion and recommendations.

\section{Origin of Accounting Standards on Segment Reporting}

The Organization for Economic Cooperation and Development (OECD) issued its first recommendation on segmental reporting in 1976. During the same period, the $4^{\text {th }}$ European directives introduced numerous requirements which were insufficient to enable users have accurate understanding of the company $(E C, 2003)$. The first exposure draft (ED) on segment reporting was issued by the International Accounting Standards Committee (IASC) in 1980.In April, 1981, the exposure draft became IAS 14 which is "reporting financial information by segment". The IAS 14 adopted mainly the industry approach and recommended that companies should publish sales, assets and results for line of business and geographical segments (Nichols, Street and Cereola, 2012,Nichols, 2007). However, owing to the numerous criticisms, a revised IAS14 (IAS14R) was issued in 1997. The IAS14R adopted the management approach by distinguishing between business and geographical segments. Moreover, following the convergence project of the IASB/FASB, IFRS 8 on operating segments was issued in 2006 which became applicable from January 2009.

Segmental reporting was regulated by SFAS 14 "financial reporting for segments of a business enterprise" in the USA in December 1976.The FASB issued SFAS 14 to assist users to analyze cash flows as well as past and future performance of corporations (Stanko, Utterback and Fitzgerald,2001). However, the US Security and Exchange Commission (SEC) and security analysts criticized SFAS 14 because of the insufficient segment information disclosed by corporations. In particular, the analysts complained of not receiving quality information on corporation's components. The contributions and criticisms of SFAS 14 led to the issuing of SFAS 131 on "disclosures about segments of an enterprise and related Information" by the FASB in June, 1997.

SFAS 131 adopted the management approach as the IAS14R, focusing on relevance rather than comparability 
(Emmanuel and Garrod, 2002). Stanko et al (2001) have argued that it is difficult to conclude whether there is improved users' ability to understand and forecast, strategize or use other information that management made available to them four years after issuing SFAS131.They questioned whether more is always better. However, Stanko et al (2001:104) sound optimistic that "if most companies follow the spirit of the SFAS 131, not just its literal definitions, most financial statement users should receive more useful information in company's segments and users should be in a better position to assess a company's past performance and its future potential". Similarly, Stanko et al (2001) argued that enterprise information in the financial reports should be comparable and consistent over time to enhance usefulness. They argued that information about an enterprise is useful it can be compared across forms (comparability) and with similar information from year to year (consistency). The survey by Pricewaterhouse Coppers (PWC) in 2007 found that investors wanted segment reporting to be consistent in order to aid their comparability of past and future performances.

Table 1: History of Standards on Segment reporting

\begin{tabular}{|l|l|}
\hline Year & Specific events \\
\hline December 1976 & SF AS 14 issued by US. FASB \\
\hline March 1980 & Exposure draft E15 on 'reporting financial information by segment' \\
\hline August 1981 & IASC issued IAS 14 on 'reporting financial information by segment' \\
\hline 1st January 1983 & Effective date of IAS 14 \\
\hline 1994 & IAS 14 (1981) Reformatted \\
\hline December 1995 & ED E51 on 'reporting financial information by segment' \\
\hline June 1997 & SF AS 131 issued by US. FASB \\
\hline August 1997 & IASC issued IAS 14R on 'segmental reporting' \\
\hline 1 July 1998 & Effective date of IAS 14R \\
\hline 30 November, 2006 & IAS 14 revised is replaced by IFRS 8 Operating Segments \\
\hline 2009 & IFRS 8 (Operating Segments) \\
\hline 1 January, 2009 & Effective date of IFRS 8 \\
\hline
\end{tabular}

Source: IASB

\subsection{Segment Reporting Under SFAS 14}

The SFAS 14 was issued by the US FASB in December 1976. SFAS 14 requires information disclosure by industry segment or geographical area. According to SFAS 14:10a, "an industry segment was a component of an enterprise engaged in providing a product or service or a group of related product and series primarily to unaffiliated customers for a profit". However, a major problem of SFAS 14 was the closed linkage to industry segment because many of the corporations reported operations in one segment. Stanco et al (2001) report that in a survey of 6,935 companies by the FASB, $25 \%$ of the surveyed companies operated in one industry segment and $43 \%$ of respondents with turnover greater than $\$ 1$ billion were single segment. SFAS 14 had little impact on segmental reporting because of the problem of industry segment definition. In the surveys by Pricewaterhouse Coppers (PWC) in 2007 and 2008, segment information was ranked among the top items important to analysts and investment professionals. Although, the respondents believed that segment information was the greatest gap in reporting today, investors expressed concerns that the management approach to segment reporting may be abused in the use of measures reported. Hence they advocated meaningful performance measures which include non-GAAP measures and the basis of their inclusion as well as reconciliation to GAAP. This is to enable them to link the main segment information disclosed with previous year information and make comparison when assessing the corporation's past performance and future prospects. Hence, the FASB replaced SFAS 14 with SFAS 131 because majority of the companies were not using products or services to distinguish their organizational performances (Albrecht and Chipalkatti,1998).

\subsection{Segment Reporting under SFAS 131 - The Management Approach}

SFAS 131 on "disclosures about segments on enterprise and related information" was issued in June 1997 but became operative after the $15^{\text {th }}$ of December, 1997. It was issued to enable external users to see companies through the eyes of management. SFAS131 wants companies to report the same internal information used in assessing segment performance and resources allocation to the external users (Alfonso, Hollie and Carol, 2012). Here, companies were to 
identify the segment(s) to disclose based on the chief operating decision-maker (COMD) organizes the company. The $\mathrm{COMD}$ is the person or group of persons whose duty is to assess the business performance and allocate resources to the different units (PWC, 2008).

The SFAS 131 report information about operating segments of an enterprise consisted of two basic disclosures. These are the operating and enterprise-wide disclosures. In the attempt to cure the deficiency of SFAS14, SFAS 131 defines operating segment as "the component of a business that: (1) engages in activities from which it may earn revenues and incur expenses (including revenues and expenses relating to transactions with other components of the same business, (2). whose operating results are regularly reviewed by the enterprise's CODM to make decision about the segment performance and resources allocation and (3) for which discrete information is available". The enterprise-wide disclosures include information on the product or service regarding revenue generated from external and major customers, geographical area etc.SFAS 131 has been criticized because the management approach lacks credence in the quantitative amount of disclosure for entity's segment as well as the incomparability of segment information for same entities (Stanco et al, 2001). Moreover, the presentation of segment performance disclosures in the same format by management made the analysis of segment performance and comparability across different entities very difficult. There were also evidences that managers of firms with greater agency problems engaged in self-interested behaviour such as empire building (Hope and Thomas, 2008,Wang et al,2011) and concealed less profitable segment in post SFAS 131 period (Berger and Hann,2007)

The success of SFAS131 was predicated on two implementation issues which were: (1) the auditor's ability to address what management classifies as segments and (2) the corporate world's ability to successfully explain and use the reported non-GAAP measures (Albreacht and Chipakatti,1998, Nichols, Street and Gray 2000). Nichols et al (2000) find mixed result on the empirical study of US global 1000 companies on the extent of companies' response to changes in geographical segment information required by SFAS 131 using their 1997 and 1998 annual reports. They found that "while more country specific data was disclosed and increased consistency of disclosures with the other parties of annual report, the problem of reporting highly aggregated geographic areas remained for a significant group of companies". Paul and Largay III (2005) argued that the management approach with significant benefit to users was compromised by uneven compliance among reporting companies and therefore it was difficult for outsiders to observe and monitor segment information. For instance, while it shed light on Enron's operations, it concealed WorldCom's due to auditor's malfeasance. There were also concerns or opportunities for accounting manipulations (Reason,2001) leading to deterioration of earning quality and predictability (Dechow, Ge and Schrand,2010).Although SFAS 131 was supposed to reduce the information gap between the users of the company's financial reports, Botosan and Stanford (2005) argued that SFAS 131 may have widened the gap by decreasing the consistency and comparability of information across firms. Moreover, Street, Nichols and Gray (2000) found the non-definition of segment profitlloss to result in the incomparability of the reports.

Nevertheless, SFAS 131 has resulted in increased segment disclosures by U.S firms and helped them to close the loopholes with respect to identifying segments (Street, Nichols and Gray,2000; Ettredge, Kwon and Smith,2002; Berger, Hann and Piotroski,2003). Also, it has provided users of financial statements with information reviewed by management to assess segment performances and allocate resources (Berger and Hann, 2003; Ethredge, Kwon, Smith and Zarouin, 2005; Nichol and Street,2007). Ewert and Wagenhofer (2005) argued that the use of management discretion has improved earnings predictability. Other benefits of SFAS 131 include: relatively low incremental cost of providing segment information, the objective and verifiable identification of segment and it was based on enterprise's internal organization which the auditors could easily identify. Behn, Nichols and Street (2002) found positive increase in the predictive accuracy of the disclosures of geographic sales under SFAS 131; this supports the FASB's position that company's segment information provides more useful information (Nichols et al, 2012). Ettredge et al (2005) examined companies that moved from single segment companies to multiple segments reporting under SFAS 131.They found an increased market's ability to predict earnings of multiple-segment companies than single segment companies.

\subsection{Comparison between SFAS 14 and SFAS 131}

The FASB replaced SFAS 14 with SFAS 131 because companies' failure to provide the required segment information. Initially SFAS 14 was issued due to calls and agitations by several groups such as the Financial Analysts Federations (FAF), financial executives, institutes, New York Stock Exchange and the Accountants International Study Group (Albrecht and Chipalkatti,1998). However, because of segment definition by industry groupings, companies exploited the vagueness in SFAS 14 by considering themselves as a single-segment company. The management approach of SFAS 131 specifies how to identify operating segments and the financial data which need to be disclosed. Moreover, the IASB 
concluded that SFAS 131 provided more useful information to users than the SFAS 14 (Nichols et al, 2012). Specifically, the adoption of SFAS 131 in the US "(1) increased in the number of segments reported and segment information provided, (2) enabled the users to see the entity through the eyes of management, (3) enhanced consistency with the management discussion and analysis (MD\&A) or other annual report disclosures, and (4) provided various measures of segment performance" (Nichols et al, 2012).SFAS 131 has also reduced the opportunity of managers to manipulate segment profits ( Hann and Lu, 2009)

Table 2. Comparison between SFAS 14 and SFAS 131

\begin{tabular}{|c|l|l|l|}
\hline S/n & Basis & SFAS 131 & SFAS 14 \\
\hline 1. & Segment definition & Management approach & Industry approach \\
\hline 2. & Vertical integration & $\begin{array}{l}\text { Operating segment with or not yet with } \\
\text { revenues }\end{array}$ & $\begin{array}{l}\text { Focused on an enterprise end products/services sold to } \\
\text { external parties. }\end{array}$ \\
\hline 3. & Disclosures & $\begin{array}{l}\text { More specific and detailed:- Operating } \\
\text { segment and enterprise }\end{array}$ & Less detailed on industry segment and geographical areas. \\
\hline 4. & Interim statement & Some segment information are reported. & $\begin{array}{l}\text { Required that segment information be reputed on an interim } \\
\text { basis. }\end{array}$ \\
\hline
\end{tabular}

\subsection{Segment Disclosures and Competitive Harm under SFAS 14 and SFAS 131}

Harris (1998) argued that companies in competitive industries took advantage of the industry approach under SFAS 14 to classify dissimilar business into one segment which helped to hide valuable business information from suppliers, customers and competitors. Botosan and Stanford (2006) confirmed Harris (1998) that under SFAS 14,US companies were less willing to disclose separately their operations in less competitive industries so that they can reduce proprietory costs and hide profit. Moreover, large firms in highly concentrated industries aggregated a number of industries into their business segments (Ettredge,Kwon and Smutti 2000).The reluctance of companies to provide segment information include multi-faceted costs like cost of increased competition (Gray, 1981) and competitive disadvantage (Emmanuel and Garrod,1992; Nerrecha,1983 \& 1990; Wagenhofer,1990). Sprouse (1969) argued that companies will disclose fewer information because of competition. However, high level competition has been found to be associated with increased disclosures (Darough and Stoughton,1990; Newman and Samsung 1990,Gigler,1994).According to Bacler and Mcfarland (1968), the impact of perceived competitive disadvantage on segmental disclosures include:

1. "Disclosure of information regarding profitable segments may attract new competitors to the industry".

2. "Disclosure of information regarding loss makers may attract takeover bids or may force company to sell their segments to improve short-term profit".

3. "Non-uniform reporting requirements at the required or global level may adversely affect international competitiveness".

Moreover, Bacler and Mcfarland (1968) stated that disclosures about line of business may expose to the competitors the company's strategies, level of overseas operations and internal integrations Tsakumi et al (2006) argued that firms exposed to greater competitive harm under SFAS 131 provided less detailed country specific revenue disclosures in geographical areas. Nichol and Street (2007) found that there is flexibility under the management approach which enabled managers to aggregate industry's segment in order to protect excess returns. Douprink and Seese (2001) found that when information for firms that no longer disclose geographic earnings was given, this reduced the ability of investors to utilize or generate private information in conjunction with public announcement of quarterly earnings which dampened trading. They also found a decline in pre-announcement private information following SFAS 131. There were differences with how materiality was defined by companies under SFAS 131 compared to SFAS 14

\subsection{A comparison of IAS 14 and IAS 14 Revised}

The IAS 14 was issued by the IASC in 1981 because of users' concerns that some managers combined segments to guide their performance on specific lines of business or saying they have no industry segment at all (Nichols and Street,2007). Unfortunately, IAS 14 allows managers to exercise judgment or discretion. Besides, the reported operations was significantly affected by industry competition (Harris 1998). Again, IAS 14 was ineffective because of its general requirements. The requirement for companies to report along significant industry and geographical segments of operations was abused by them to report one industry segment. These concerns led to the dropping of the industry 
approach for the management approach by the FASB and IASC in 1997. IAS 14 was revised because (1): it permitted too many alternatives in order to accommodate the diverse constituencies, (2) it did not provide guidance and sufficiently detailed definitions for key items, and (3) it did not require additional financial and descriptive information about segment. Moreover, IAS 14 permitted alternative interpretations in order to satisfy the IASC's wide stakeholders. Hence the calls by organization such as: OECD, IOSCO and UN Working Group on IASC in 1990 to expand the requirements for segment disclosures and address the issues relating to the implementation of IAS 14 (Albreacht and Chipalkatti,1998). In the late 1990s, IOSCO considered endorsing some core IASs for cross-border listings as well as the US (FASB). Also Canada Accounting Standards Board (ACSB) during the revisit of her segmental reporting pushed the IASC to embark on the same mission of revising IAS14.McConnell and Porter (1995) argue that international analysts found substantial rooms for improvement of segment reporting because:

1. Many companies hid under the broad definitions to argue they had no industry segments

2. There were needs for more segment information.

3. There was improper articulation and omission of the organizational unit a segment was reported in financial statements under IAS 14.

IASC replaced IAS 14 with IAS 14R in 1997 because of the above deficiencies, agitations and scrutiny by users' group and similar projects by the US.FASB and ACSB which exerted pressures on the IASC (Nichols et al, 2012). Consequently, the Steering Committee of the IASC concluded that IAS 14 should be revised in order to: (1) reduce the alternative practices and enhance understandability and consistency of segment information between enterprises, (2) provide clear guidance to identify and measure segment revenue, expenses, results and assets, and (3) include more segment information useful to other investors and users (IASC,1994). The resulting IAS 14R requires that segments should be reported based on the management approach.

The IAS14R provides two-tier structure for reporting segments along line of business and geographical segment using the risk- reward approach which helps to (1) the define and identify segments and (2) to determine the primary and secondary reporting requirements (IASC,1997).A primary motivation for IAS 14R by IASC was to disaggregate segments belonging to the similar industry but differing in risk and reward composition (Albrecht et al,1998). Thus IAS 14R requires companies to separately report two segments having similar product or service but differing in risk and reward profile. Under the IAS 14, these differences may be ignored. A major challenge for auditor was in determining whether the organization was properly structured into segments and tiers, and the reliance on the management's risk-reward profiles.

In comparison to IAS 14, IAS 14R increased the items disclosed for primary segments. It requires the disclosure of the following items by entities: assets, liabilities, revenues (external and inter-segment), depreciation, capital expenditures, result, reconciliation etc. Moreover, IAS 14R requires the disclosure of assets, capital expenditures and revenue for secondary segments. Though important, IAS 14R does not require disclosure of cash flow information for segment. Nichols and Street (2002) found that the transition from IAS 14 to IAS 14R resulted in: "(1) a significant increase in the items disclosed for primary and secondary segments, (2) a significant increase in the consistency of primary segment information with the introductory annual report materials and MD \&A, and (3) a significant decrease in companies' claims of operating in one segment". They found that although a number of companies claimed operating in one segment, their annual reports showed the existence of multiple line of business segments.

\subsection{Comparison between IAS $14 R$ and SFAS 131}

Although the information disclosed under US GAAP was not significantly different from IAS/IFRS based information (Ashbaugh and Olsson,2002), the differences between the two standards on segment reporting have been considered very important (Dore and Vilu 1998). Glaum and Street (2003) found that US GAAP firms comply more with the standards on segment reporting than IAS firms. Leuz (2003) reported that there were no significant differences on information asymmetry between US GAAP and IAS/IFRS companies.

Despite that IAS 14R and SFAS 131 are on segmental reporting, both are significantly different. First, the SFAS 131 adopted a management approach with no risk-reward approach while IAS 14R used the risk-reward approach. The differences are attributed to users' needs and the financial reporting environment. For instance, IASC decided to choose the risk-reward approach because of the easy understandability and applicability across cultures and financial markets without the information being compromised (Nichols et al,2012). As part of the IASB's due process, IASB found that majority of the users favoured the management approach of SFAS 131 over IAS 14R because of its risk and reward qualification. Second, homogeneity in management style, organization regulatory and investors' perspective and financial market environment makes the management approach very applicable (Nichols et al,2012).

The primary differences between SFAS 131 and IAS 14R are : One, SFAS 131 does not disclose segment 
liabilities unlike the IAS 14R; Two, SFAS 131 does not report secondary segment reporting like IAS 14R. SFAS 131 requires revenues from transactions with external customers for each product or services for reportable segment not based on differences in products or services to be disclosed .Three, SFAS 131 requires that for each reportable segment not based on geography, the entities must disclose revenues and other long-lived assets for the country of domicile and other country accounting for $10 \%$ or more of the revenues and/or assets. Four, IAS 14R wants firms to make a choice between LOB or geographic segment in disclosing for primary segment while SFAS 131 permit the use of mixed or both reportable segments. Five, IAS 14R concentrates on segment information which is consistent with the consolidated statements whereas SFAS 131 concentrates on information used by management for business operations and it also reports non-GAAP measures. The introduction of IAS 14R increased the disclosures on segment (Streets and Nichols, 2002).

\section{IFRS 8 (Operating Segments)}

IFRS 8 on Operating Segments highlights information management think are useful for key decisions making. The IFRS 8 was issued by IASB to replace IAS 14R in November 2006.It became applicable from January $1^{\text {st }} 2009$. The standard aligns segmental disclosures in IAS 14R with the SFAS 131.In fact, IASB adopted the requirements of the SFAS 131 almost in its entirety (PWC,2008) and the management approach of SFAS 131 because of its immense merits (Nichols et al,2012). IFRS 8 is a ground-breaking standard because it represents IASB's bold attempt to ensure firms disclose information 'through the eyes of management'. However, IFRS 8 was contentious with two main issues. The first issue was the challenge faced by firms to identify the person or persons of the CODM while the second issue was the use of non-IFRS measures to report segmental performance for the first time. Like SFAS 131, IFRS 8 uses the management approach to identify and measure the financial performance of the operating segments of entities. This is in contrast to the risk and reward approach of IAS14R. Sacho (2007) predicted that the use of management approach would make presentation of external segment reports easier and less costly, make segment information to be more informative from user's perspective and increase financial reporting in segments.

Unlike IAS 14R, IFRS 8 does not prescribe segmentation along business or geographic segment but operating segment. IFRS 8 defines the "entity-wide disclosures", by products or services, geographic areas and major costumers. IFRS 8 also requires entities to make disclosures that would enable users to evaluate the nature and financial effects of their business activities and the economic environment of operation. KPMG surveyed 81 companies in 10 sectors among the fortune global 500 companies in the EU in 2009 and found that there was increase in the average number of segment reported from 4.6 under IAS 14 to 5.2 under IFRS 8 (KPMG,2010). The survey by Deloitte on IFRS 8 disclosures by 100 listed companies within the largest 1000 listed companies in the United Kingdom in 2012 found that $69 \%$ of the companies presented the same segmentation under IAS14, the average number of segments (which was 3) was virtually unchanged under IFRS 8 compared with IAS 14; and 78\% disclosed identity of COMD, 37\% and $11 \%$ of the sampled companies identified the board of directors and chief executives as the COMD.

Crawford, Extrance, Helliar and Power (2012) reported increase in the average number of operating segments from 3.30 to 3.56 and geographical segments from 3.68 to 4.09 but there was decline in the average number of items per operating segment (from 7.02 to 6.43). The result of the interviews of preparers, auditors and users revealed that while preparers welcomed the management approach and that IFRS provides more useful information, auditors and users were less enthusiastic; users were concerned about companies' flexibility to hide unfavourable results and the lack of comparability between companies. Mardini, Crawford and Power (2012) found that although Jordanian companies providing segment information increased from $33 \%$ to $43 \%$, there was no significant difference in the number of segment disclosed under IAS14 and IFRS 8. IFRS 8 maintains the disclosure requirement for segment liabilities if the amounts are regularly provided to the COMD even though such disclosure would create divergence with SFAS 131.

Table 3. Key Differences between IFRS 8 and IAS 14

\begin{tabular}{|c|l|l|l|}
\hline S/No & Bases & IFRS 8 & IAS 14 \\
\hline 1. & Operating segment & $\begin{array}{l}\text { Business activities that earn revenues or raw expenses } \\
\text { whose operating results are regularly reviewed by COMD }\end{array}$ & $\begin{array}{l}\text { Business or geographic based components } \\
\text { in terms of risks and returns that are } \\
\text { different from other components. }\end{array}$ \\
\hline 2. & Applied to: & $\begin{array}{l}\text { Entities whose equity or debt securities are publicly traded } \\
\text { or that issue equity or debt securities or financial statements } \\
\text { with a regulatory organization for IPO purposes. }\end{array}$ & $\begin{array}{l}\text { Entities that have public traded securities } \\
\text { or are no process of issuing them in a } \\
\text { public market. }\end{array}$ \\
\hline 3. & $\begin{array}{l}\text { Information in } \\
\text { operating segment }\end{array}$ & Information management uses to run the business & $\begin{array}{l}\text { Financial information presented in the } \\
\text { consolidated financial statement. }\end{array}$ \\
\hline
\end{tabular}




\begin{tabular}{|c|l|l|l|}
\hline 4. & $\begin{array}{l}\text { Measurement of } \\
\text { segment disclosure }\end{array}$ & Management information reported to the COMD & IFRS- compliant financial information. \\
\hline 5 & $\begin{array}{l}\text { Definition of } \\
\text { reported terms }\end{array}$ & $\begin{array}{l}\text { Reported items are not defined } \\
\text { Convergence with US }\end{array}$ & $\begin{array}{l}\text { Reported items are defined } \\
\text { Segment reporting agrees with financial } \\
\text { statements }\end{array}$ \\
\hline
\end{tabular}

Source: Adapted from PWC (2008) and IFRS Foundation (2012)

\section{Implications of IFRS Adoption (IFRS 8) on Segment Reporting}

Segment reporting has been problem for standard setters (Rennie and Emmanuel, 1992; Emmanuel et al., 1999; Edwards and Smith, 1996, Crawford, Ferguson, Helliar and Power,2013). For example, some of the concerns about IAS14R include: the disclosures to be made by companies, the aggregation of segments to mitigate against claims of competitive disadvantage (Nichols et al, 2007) and the quality and quantity of reported segment information (Street \& Nichols,2002). Moreover, the introduction of IFRS 8 has also been surrounded with controversies and politics (Crawford, Helliar and Power, 2010b; Perrin, 2012).

Recent studies on IFRS 8 concluded that the number of segments and geographic areas disclosed have increased on the average (Crawford, Extrance, Helliar and Power, 2012, Mardini, Crawford and Power, 2012). In addition, there were` various sectors and industries reporting practices (Crawford, Extrance, Helliar \& Power, 2012). Nichol, Street \& Cereola (2012) found a decrease in the number of segment liabilities and capital expenditures that were reported at the entity-wide level by blue chip companies in the European Union. Moreover, the standards did not support the comparison of segment profitability measures and detailed disclosures of non- IFRS measures.

There are some concerns following the initial adoption of IFRS 8 by stakeholders (Crawford, Helliar and Power,2010b; Perrin,2012).These concerns include: IFRS 8 was based on the approach adopted by SFAS 131, the risk of lower quality disclosures, concerns about who the CODM is/are, incomparable information, the lack of consistency in reporting formats for operating segments, the potential for companies to restrict their disclosures on geographical segments, users suspicion that preparers could choose not to include information that it does not require and liabilities to be analyzed on a segmental basis. Moreover, users are not able to determine returns on capital for each segment, because only information on the asset side is provided. These concerns have made some to question whether IFRS 8 is better (Aleksanyan and Danbolt, 2015)

In the attempt to address these concerns, the IASB and other research groups have embarked on the postimplementation reviews and researches into IFRS 8.The IASB published report in July 2013 concluded that IFRS 8 has achieved its objectives by improving financial reporting. However, the IASB considered the following items needed further examination : (1) the idea of the CODM which is not easy to identify, outdated and difficult in practice (2) the challenge of preparing and presenting the reconciliations. Besides, the areas of segment disclosures that needed to be improved upon include: (1) where there is change in the basis of segment reporting by an entity (2) helping investors to calculate the total operating results through defining some of the line items (3) reducing difficulties posed by the aggregation of operating segments and (4) improving the reconciliations required by IFRS 8.

\section{Conclusion and Recommendations}

In this paper we examine the usefulness and implications of various segment standards reporting issued by the major standard setters like the IASB and FASB. The presentation of segment information in the notes to the accounts is to provide users with information about the different business and geographical segments of a diversified entity's operations in order to enable investors and other users to make informed decision about the entity. Segment data of a firm is very important because it can aid its comparability with other firms in the industry from one year to another with similar information. Notwithstanding the importance of segment disclosures, it represents one of the greatest gaps in the financial reporting of today. Many companies are reluctant to disclose segment information because of the strategic and competitive harms such as revealing a company's strategies, level of overseas operations and internal integrations to competitors which may be associated with its disclosures.

The advocacies for companies to disclose adequately segment information was to enable users to make informed decisions. This also resulted in the issuing of various segment standards such as SFAS 14 and 131, 1AS 14, IAS 14 Revised and IFRS 8. However, revisions or replacement of the standards on segment reporting were due to the reported deficiencies or criticisms by users and other stakeholders. Following the convergence project of the IASB and US FASB, 
IFRS 8 was adopted for reporting segment information. Although IFRS 8 has resulted in increased segment disclosures, there are a lot of concerns on IFRS 8 such as: being based mainly on SFAS 131 management approach, the risk of lower quality disclosures, definitions of who the CODM is/are, incomparable information, the lack of consistency in reporting formats for operating segments, the potential for companies to restrict their disclosures on geographical segments, users suspicion that preparers could choose not to include information that it does not require and liabilities to be analyzed on a segmental basis and users' inability to determine returns on capital for each segment because only information on the asset side is provided. As the global campaign for the adoption of IFRS continues among the developing and reluctant developed countries, these concerns are significant enough to undermine and diminish the usage of IFRS 8.Therefore the paper recommends more post-implementation reviews by IASB and other researchers into these concerns and other problem areas in order to address the deficiencies and improve the quality of the segment reporting standards.

\section{References}

Aleksanyan, M. and Danboltm J. (2015). Segment Reporting: Is IFRS 8 Really Better? , Accounting in Europe.

Albrecht, D.W. and Chipalkatti, N. (1998).'New segmental reporting', The CPA Journal May, pp. 46-51.

Ammanuel,C.R. and Garrod, N.(1992).'On the segment identification issue', Accounting and Business Research,vol.17,no.67

Archambault, J.J. and Archambault, M.E (2003).'A multinational test of determinants of corporate disclosures', The International Journal of Accounting,vol.38, pp.173-194

Ashbaugh H. and Olsson,B (2002).'An explorary study of the valuation properties of cross-listed firms, IAS and U.S.GAAP earnings and book values', The Accounting Review, vol.77,pp.107-126.

Backer, M.M. and McFarland,W. (1968). External reporting for segments of a business. National Association of Accountants.

Behn, B. K., Nichols, N. B. and Street, D. L. (2002).'The predictive ability of geographic segment disclosures by U.S. companies: SFAS No. 131 vs. SFAS No. 14', Journal of International Accounting Research, vol.1, pp.31-44.

Berger, P. G. and Hann, R. N. (2007).Segment profitability and the proprietary and agency cost of disclosure. The Accounting Review,vol.82,pp 869-906.

Berger, P. G., Hann, R. N., and Piotroski, J. D. (2003).'The impact of SFAS No. 131 on information and monitoring', Journal of Accounting Research, vol.41,no.2,pp.163-223

Boatsman, J.R., Behn, B.K. and Patz,D.H. (1993).'A test of the use of geographical segment disclosure', Journal of Accounting Research,vol.31,pp.46-64 Supplement

Botosan, C. A. (1997).'Disclosure level and the cost of equity capital', Accounting Review,vol.72, no.3, pp.323-349.

Botosan, C.A. and Standford, M. (2005). 'Managers' motives to withhold segment disclosures and the effects of SFAS No.13 in analyst Information environment', The Accounting Review ,vol.80,no.3, pp.751-771

Crawford, L., Helliar, C.V. and Power, D.M. (2010). IFRS 8:Exploring stakeholder perceptions of the new standard and its EC endorsement process. ICAEW Briefing Paper, ICAEW, London.

Crawford, L., Helliar, C.V and Power, D.M. (2010b).Politics or accounting principles: Why was IFRS 8 so controversial? ICAEW Briefing Paper, ICAEW, London

Crawford, L., Extrance,H., Helliar, C.V. and Power, D.M. (2012). Operating segments: The usefulness of IFRS.ICAS Insight, The Institute of Chartered Accountants in Scotland, Edinburgh

Crawford, L., Ferguson,J., Helliar, C.V. and Power, D.M. (2013).'Control over accounting standards within the European Union:The political controversy surrounding the adoption of IFRS 8',Critical Perspectives on Accounting

Damough, M. and Stoughton,N. (1990). 'Financial disclosure policy in an entry game', Journal of Accounting and Economics, vol.12,pp. $219-243$

Deloitte (2012).Pieces of eight: Surveying IFRS 8 disclosures. Deloitte LLP https://www.deloitte.com/assets/Dcom.../uk-audit-pieces-ofeight.pdf

Dove, R. and Vilu (1998). 'Segmental reporting IAS Vs US GAAP',Accountancy,vol. 122,no.1259, pp.64-65 July

Drather-Kingsey, J.\& Meet,G. (2004).The effect of revised IAS 14 on segment reporting by IAS companies.European Accounting Review, 13(2),213-234.

Edwards, P. and Smith, R.A. (1996).Competitive disadvantage and voluntary disclosures: The case of segmental reporting. British Accounting Review, 28, 155-172.

Emmanuel, C.R., Garrod, N.W., McCallum, C.\& Rennie, E.D. (1999). 'The impact of SSAP 25 and the 10\% materiality rule on segment disclosure in the UK', British Accounting Review, vol.31, pp.127-149.

Emmanuel, C. and Garrod,N. (2002). 'On the relevance and comparability of segmental data', Abacus, vol.38,no.2, pp.215-234.

Ettredge, M.,Kwon, S.Y. and Smith, D. (2002). 'Security market associated with SFAS No. 131 reported business segments', Review on Quantitative Finance and Accounting,vol.18,pp.323.

Ettredge, M., Kwon, S. and Smith, D. (2002b). 'Competitive harm and companies' positions on SFAS No. 131', Journal of Accounting, Auditing and Finance, vol.17,no.2,pp. 93-109

Ettredge, M., Kwon, S., Smith, D.and Zarowin, P. (2005). 'The impact of SFAS No. 131 business segment data on the market's ability to anticipate future earnings', The Accounting Review, vol.80,no.3, pp.773-804. 
FASB (1997) SFAS 131.Disclosure about segments of an enterprise and related Information June. 1997.

Gigler, F. (1994). 'Self-enforcing voluntary disclosure', Journal of Accounting Research, pp.224-240. Autumn.

Glaum, M. and Street, D. (2003). 'Compliance with the disclosure requirements of Germany's new market: IAS Vision US GAAP', Journal of International Financial Management and Accounting, vol.14,no.1, pp.64-190.

Gray, S.J. (1981).Segmental or disaggregated financial statements in T. A. Lee (ed.) Developments in Financial Reporting, Oxford Phillip Alan Publishers Ltd.

Gregory, H. and Pascale, T. V. (2010). An analysis of segment disclosures under IAS 14 and IFRS 8. Retrieved from http://ssrn.com/ abstract $=1615430$

Haller, A. and Park, P. (1994).'Regulation and practice of segmental reporting in Germany', The European Accounting Review,vol.3, no.3, pp.563-580.

Hann,R.N. and Lu,Y.(2009).'Earnings management at the segment level', Marshall School of Business, working paper no.MKT 111-128

Haris, M.S. (1998). 'The association between competition and managers' business segment reporting decision', Journal of Accounting Research, vol. 36,no.1, pp.111-128

Hermann, D. and Thomas, W (1996). 'Segmental reporting in the European Union: Analyzing the effects of country, size, industry and exchange Market', Journal of International Accounting and Taxation, vol.5,no.1, pp.1-20.

Hermann, D. and Thomas, W. (2000a).'A model of forecast precision using segment disclosures: implications for SFAS No. 131', Journal of International Accounting, Auditing \& Taxation, vol.9,no.1,pp.1-18

Herrmann, D., and Thomas, W. (2000). 'An analysis of segment disclosures under SFAS No. 131 and SFAS No. 14', Accounting Horizons,vol.14,no.3, pp.287-302

Hope,O and Thomas,W. (2008).'Managerial empire building and firm disclosure', Journal of Accounting Research,vol.46. pp 591- 626

Hope Ole-Kristian,W.B. Thomas and Gly Winterbotham (2009). 'Geographic earnings disclosure and trading volume', Journal of Accounting and Public Policy, vol.28,no.3,pp.167-188 May-June.

IASC (1994). IAS 14, Reporting financial information by segment. London: IASC.

IASC (1997). IAS 14R, Segment reporting. London: IASC.

IASB (2006). IFRS 8: Operating segment, London, IFRS Foundation.

Jahmani, Y. (2003). 'The impact of segmental reporting disclosure on a firm's perceived risk', International Journal of Commerce and Management, vol.12,no.2,pp.102-122.

KPMG (2010). The application of segment reporting. IFRS 8. KPMG IFRG Limited.

Knutson, P.H. (1993). Financial reporting in the 1990s and beyond, Associaton for Investement Management and Research (AIMR)

Lambert, F., Leuz, C. and Verrecchia, R. E. (2007). 'Accounting information, disclosure and the cost of capital',Journal of Accounting Research,vol.45, no.2, pp.385-420.

La Portal, R. Lopez-de-Silanes, Asheifer and Vishny, R. (1998). 'Law and Finance', The Journal of Political Economy, vol.106,no.61,pp. 1113-1155.

Leuz, C. (2003).'IAS versus U.S. GAAP: Information asymmetry-based evidence from Germany's new market', Journal of Accounting Research, vol.41,no.(3), June

Mardini,G.,Crawford, L and Power, D (2012). 'The impact of IFRS 8 on disclosure practices of Jordanian companies', Journal of Accounting anf Emerging Econmoics,vol.2,no.1,pp. 67-90

McConnell, $\mathrm{P}$ and Porter, $\mathrm{P}$ (1995).IASC and FASB proposals would enhance segment reporting. CPA Journal.

NASB (2008): SAS 24: On segment reporting, Lagos, NASB.

Newman, P. and Sansing, R (1990). 'Disclosure policies with multiple users', Journal of Accounting Research.

Nichols, N. B.and Street, D. L. (2002). 'LOB and geographic segment disclosures: An analysis of the impact of IAS 14 revised', Journal of International Accounting, Auditing and Taxation,vol.11,no.2, pp.91-113

Nichols, N.B. and Street, D.L. (2007).'The relationship between competition and business reporting decisions under the management appraoch of IAS 14 revised', Journal of International Accounting,vol.16, pp.51-68.

Nichols, N.B., Street, D.L. and Gray, S.J. (2000).'Geographical segment disclosure in the United States reporting practices enter a new era', Journal of International Accounting Auditing and Taxation, vol.9,no.1, pp.59-82.

Nichols,N.B., Street,D.L. and Cereola,S.J. (2012). 'An analysis of the impact of adopting IFRS 8 on the segment disclosures of European blue chip companies', Journal of International Accounting, Auditing and Taxation,vol.21, pp.79-105

Nobes, C. and Parker, R. (2000): Comparative international accounting. Pearson Education Limited .

Park, J. C. and Shin, Y. C. (2009). The impact of increased segment disclosure on insider trading profits: Evidence from SFAS No.131. Retrieved from http://www.af.polyu.edu.hk/jcae_af/2010/paper_c/Session\%201A.2.pdf

Paul, J.W. and Largay III, J.A. (2005). 'Does the management approach contribute to segment reporting transparency?', Business Horizons,vol.48,no.4, July-August, pp.303 -310

Perrin, S. (2012). Challenging IFRS 8. www.accountancylive.com

Piotroski, J. D. (1999).'The impact of newly reported segment information on market expectation and stock prices'. Working paper,University of Chicago, Chicago IL.

Pricewaterhouse Cooper (PWC) (2008). A practical guide to segmental reporting. www.PWC/lfrs retrieved on 11/8/10

Rennie, E.D. and Emmanuel, C.R.(1992). 'Segmental disclosure practice: Thirteen years on', Accounting and Business Finance, vol.22,no.86, pp.51-159

Sacho, Z.Y. (2007). 'IASB adopts a management reporting approach to segmental reporting', Accountancy March 
SFAS 14: Financial reporting for segments of business enterprises

SFAS 131: Disclosures about segment of an enterprise and related information,

Spouse, R.(1969).'Diversified views about diversified companies', Journal of Accounting Research,pp.137-159 Spring.

Stanko, B.B., Utterback and Fitzgerald, J. (2001). 'Segmental reporting: The aftermath effects of statement of financial accounting standards no.131', Journal of Applied Business Research

Street, D., Nichols, N. and Gray, S. (2000). 'Segment disclosures under SFAS no. 131: Has business segment reporting improved?', Accounting Horizons, vol.14, no.3,pp.259-285.

Street, D.and Bryant, S.M (2000).Disclosure level and compliance with IASs: A comparison of companies with and without US listing and fillings. The International Journal of Accounting,vol.35,no.3, pp. 305-329.

Street, D.L and Gray, S.J. (2001). Observance of international accounting standards. ACCA Research Report No. 74 London ACCA.

Street, D. and Nichols, N.B. (2002). LOB and geographical segments: An analysis of the impact of IAS 14 Revised. Journal of International Accounting, Auditing and Taxation, II(2),91- 93.

Tangi, R. and Znao,J. (1999). 'A look at segmental reporting practices of some fortune 500 components', The Journal of Corporate Accounting and Finance,vol.10,no.3,pp.127-143.

Tsakumis, G.T., Doupnik, T.S.and Seese, L.P (2006). 'Competitive harm and geographic area disclosure under SFAS 131',Journal of International Accounting, Auditing and Taxation, vol.15,no.1, pp.32-47.

Verrecchia, R. (1983). 'Discretionary disclosure', Journal of Accounting and Economics,pp.179-194.

Verrecchia, R. (1990). 'Endogenous proprietary costs through firm interdependence'. Journal of Accounting and Economics,vol.12, pp. $245-250$

Wagenhofer, A. (1990). 'Voluntary disclosures with a strategic opponent'. Journal of Accounting and Economics, vol.12, pp341-363.

Wang,Q., Ettredge,M,Huang,Y and Sun,L.(2011).' Strategic revelation of differences in segment earnings growth', Journal of Accounting and Public Policy, vol.30,pp 383-392 